\title{
ADOPSI BEST PRACTICE LOKUS STULA MERUPAKAN CIKAL BAKAL UNTUK DIADAPTASIKAN PADA RANCANGAN AKSI PERUBAHAN MELALUI KEY SUCCESS FACTORS
}

\author{
WELLIE ANNALIA \\ Widyaiswara BPSDM Provinsi Riau \\ Email : iingwellie@gmail.com
}

\begin{abstract}
ABSTRAK
Kegiatan stula atau studi lapangan merupakan cikal bakal dari rancangan aksi perubahan kepemimpinan administrator dan kedua mata pelatihan ini yaitu Mata Pelatihan stula Kinerja Organisasi dan Mata Pelatihan Aksi Perubahan Kinerja Organisasi berada dalam Agenda Aktualisasi Kepemimpinan . Peran Widyaiswara sebagai pembimbing sangat mendukung dalam menggali potensi yang dimiliki peserta stula. Kerangka berfikir stula Kinerja Organisasi pada Pelatihan Kepemimpinan Administrator merupakan kolaborasi dari agenda kepemimpinan kinerja, agenda aktualisasi kepemimpinan serta agenda Manajemen Kinerja dapat dibentuk berlandaskan organisasi berkinerja tinggi dalam menemukan Best Prectice dari Lokus stula dengan berbagai strategi dan manajemen kinerja pelayanan publik yaitu melalui leason learnt dalam mengadopsi semua key sucses factor dari lokus yang dituju dan mengadaptasikan keunggulan tersebut dalam pelaksanaan tugas diinstansi peserta melalui Rancangan aksi Perubahan yang sebelumnya dilakukan sharing sesama anggota kelompok dalam acara berbagi yang merupakan cikal bakal dari Rancangan Aksi Perubahan Peserta .Beberapa komponen stula yang terkait dengan Pelatihan Kepemimpinan Administrator adalah Profil instansi penyelenggara pelayanan publik sesuai lokus, deskripsi kinerja organisasi pelayanan publik, Key Sucses Factor Pelayanan Publik sesuai lokus, dan keberlangsungan keunggulan strategi dan manjemen kinerja pelayanan publik serta leason learnt hasil stula yang diadopsi lokus dan diaptasikan ditempat pelaksanaan tugas peserta dengan simpulan Organisasi Kinerja harus melakukan inovasi untuk memenuhi tuntutan pelayanan publik yang semakin berkembang.
\end{abstract}

Kata Kunci : Best Practice, Key Succes Factors, Metode Pembelajaran

\section{PENDAHULUAN}

Suatu fenomena khusus dalam peradaban manusia yang bergerak terus dalam masyarakat global dan merupakan bagian dari proses masyarakat global disebut dengan Globalisasi.. Globalisasi mengandung suatu pengertian akan hilangnya satu situasi dimana berbagai pergerakan barang dan jasa antar negara diseluruh dunia dapat bergerak bebas dan terbuka dalam perdagangan (Munawir, 2012:1). Secara lebih umum globalisasi adalah gambaran peningkatan keterkaitan dan ketergantungan antarbangsa dan antarmanusia di seluruh dunia melalui perdagangan, investasi, perjalanan, budaya populer, dan bentuk -bentuk interaksi yang lain sehingga batas - batas suatu negara menjadi bias proses (Hubeis : 2010). Keberadaan globalisasi membuka satu negara terhadap negara lain, yang masuk bukan hanya barang dan jasa, tetapi juga teknologi, pola konsumsi, pendidikan, nilai budaya dan lain-lain. Globalisasi menyentuh seluruh aspek penting kehidupan dan kehadiran teknologi informasi dan teknologi komunikasi mempercepat akselerasi proses globalisasi ini (Munawir : 2012). Salah satu dampak globalisasi adalah perkembangan Teknologi, Informasi dan Komunikasi (TIK) atau Information and Communication Technologies (ICT) (Sari : 2014).

Berdasarkan Peraturan Kepala Lembaga Administrasi Negara Nomor 16 Tahun 2019, tentang Pelatihan Kepemimpinan Administrator (PKA), bahwa salah satu tujuan dari agenda studi lapangan (stula) bertujuan agar peserta PKA mampu merancang pengembangan potensi diri, melakukan inovasi terkait pengelolaan tugas dan fungsi pada unit instansinya, membangun budaya kerja untuk efektivitas kepemimpinan dan mengadopsi serta 
mengadaptasi keunggulan pengelolaan tugas dan fungsi organisasi lain ke unit kerja masingmasing. Selanjutnya demi tercapainya tujuan yang diinginkan maka dilakukan studi lapangan untuk (lesson learnt)

SDM yang berkualitas dibutuhkan dalam memfasilitasi pelaksanaan kegiatan. Oleh karena itu, guna menciptakan sumber daya manusia yang kompeten dan ahli diperlukan studi lapangan untuk dapat mengobservasi, identifikasi, adopsi dan mengadaptasi yang menjadi keunggulan pada lokus studi lapangan. Studi Lapangan merupakan suatu metode pembelajaran yang diterapkan untuk menambah wawasan peserta dalam melihat keunggulan instansi yang dituju untuk dijadikan pembelajaran. Kegiatan ini dilaksanakan dengan melakukan suatu pengukuran terhadap kualitas kebijakan diklat, produk, program, dan strategi sebuah organisasi, dan membandingkan mereka dengan standar yang digunakan oleh organisaisi lainnya. Kegiatan ini membekali peserta dengan kemampuan untuk mengadopsi keunggulan instansi yang dikunjungi untuk dapat dijadikan pembelajaran atau rujukan peserta dalam membuat laporan kertas kerja studi lapangan, baik secara kelompok maupun individual.

Faktor Pembimbing dalam membimbing, menfasilitasi dan mendampingi peserta juga merupakan faktor kunci yang menentukan keberhasilan studi lapangan Dalam Pelaksanaan Studi lapangan (Stula) ada 2 (dua) jenis pembimbing yaitu Pembimbing Utama (Instrukstur WI/lainnya), yaitu yang ditunjuk oleh penyelenggara untuk melakukan proses pembimbingan di kelas maupun dilapangan. Dengan tugas memberi penjelasan dan bimbingan tentang kegiatan studi Lapangan, meliputi pelaksanaan bembingan di kelas dan bimbingan di lapangan. dan yang kedua adalah Pembimbing dari Instansi yang menjadi objek Studi Lapangan, dengan tugas sebagai berkut: 1) Memberi penjelasan Gambaran Umum daerah studi 2) Memberi bimbingan di lapangan 3) Memfasilitasi, menyediakan data-data yang dibutuhkan.

Studi Lapangan merupakan suatu proses pembelajaran yang sangat terkait dengan konsep sistem pembelajaran yang dianut oleh Lembaga Administrasi Negara (LAN-RI). Untuk itu, perlu dilihat keterkaitan lapangan yang akan dibahas dengan materi pelatihan yang telah diterima oleh peserta Pelatihan Kepemimpinan Administrator, yang diharapkan akan menunjang kompetensi sasar dari program pelatihan. Leason Learnt Kepemimpinan Kinerja adalah

1. Peran Kepimpinan,

2. Inovasi Pelayanan,

3. Kompetensi dan pemberdayaan SDM

4. Pembangunan Jejaring Kerja dan Kolaborasi Pemangku Kepentingan

5. Penerapan Manajemen Kinerja

6. Penerapan Manajemen Resiko

7. Planning \& Budgeting

8. Pemanfaatan Teknologi dll.

Lokus yang akan dituju berkaitan dengan teknologi informatika karena Perkembangan teknologi informasi dan komunikasi dengan derasnya arus globalisasi merupakan dua proses yang saling terkait satu sama lain. Keduanya saling mendukung. Tak ada globalisasi tanpa kemajuan teknologi informasi dan komunikasi (Mubah, 2011:302). Perkembangan informasi dan teknologi memiliki peran penting dalam era komunikasi modern saat ini. Telah banyak para pengguna teknologi canggih yang meng-up date perkembangan informasi dari waktu ke waktu dengan akses mudah (Gunawan, 2013). Kemudahan berkomunikasi dan teknologi yang memadai membuat manusia tidak sulit untuk mendapatkan informasi. Kini dengan hanya satu alat, kita dapat mengetahui berbagai informasi baik informasi dari sumber terdekat hingga 
informasi dari sumber yang jauh tanpa perlu berpergian. Tentunya kemudahan ini bermanfaat sekali untuk manusia yang semakin haus akan informasi. Sebagaimana dikemukakan oleh Moedjiono (2012:1) "memasuki akselerasi proses globalisasi yang dramatis difasilitasi oleh revolusi di bidang teknologi khususnya Teknologi Informasi dan Komunikasi, yang mentransformasikan masyarakat dunia memasuki era yang kita kenal dengan "era informasi".

Studi Lapangan merupakan suatu metode pembelajaran yang diterapkan untuk menambah wawasan peserta dalam melihat keunggulan lembaga diklat yang dituju untuk dijadikan pembelajaran. Kegiatan ini dengan melakukan suatu pengukuran terhadap kualitas kebijakan diklat, produk, program, dan strategi sebuah organisasi, dan membandingkan mereka dengan standar yang digunakan oleh organisaisi lainnya. Kegiatan ini membekali peserta dengan kemampuan untuk mengadopsi keunggulan organisasi yang dikunjungi untuk dapat dijadikan pembelajaran atau rujukan peserta dalam membuat laporan kertas kerja studi lapangan, baik secara kelompok maupun individual.

Studi Lapangan merupakan suatu proses pembelajaran yang sangat terkait dengan konsep sistem pembelajaran yang dianut oleh Lembaga Diklat dalam penerapan PBM Studi Lapangan yaitu melalui pendekatan pembelajaran Problem Based Learning (PBL). Proses Pembelajaran dengan pendekatan Problem Based Learning adalah suatu pendekatan pembelajaran dengan melihat permasalahan sebagai bahan untuk dicarikan solusinya dalam memecahkan masalah. Sehingga perlu dilihat keterkaitan Lapangan yang akan dibahas dengan materi pelatihan yang telah diterima oleh peserta pelatihan Manajemen Risiko, yang akan menunjang kompetensi Dasar dari program pelatihan. Dengan demikian apabila memungkinkan, perlu juga dirancang kegiatan Kuliah Lapangan yang menunjang PBM Studi Lapangan sesuai dengan tema yang akan diangkat dengan topik-topik yang relevan dengan daerah kajian. Dengan demikian tahap pertama Koordinator Pembimbing Studi Lapangan menetapkan TEMA dan TOPIK dari Studi Lapangan, yang merupakan bagian dari PBM Materi Pelatihan Studi Lapangan. Dalam kegiatan PBM Materi Pelatihan Studi Lapangan ada beberapa hal yang perlu diperhatikan, diantaranya: a) Kompetensi Dasar dan Kurikulum dari Program Pelatihan (Relevan dengan Materi Pelatihan Studi Lapangan) b) Waktu Pelaksanaan c) Jumlah Pertemuan d) Penentuan Lokasi daerah Kajian e) Kunjungan Lapangan f) Seminar

Tujuan pembimbingan terhadap peserta stula yang berkapasitas sebagai pejabat administrator dilingkungan pemerintah provinsi Riau adalah agar peserta dapat mengadopsi best practice melalui key success factor dari lokus stula yang dalam hal ini adalah Dinas Kominfo Provinsi Jawa Barat untuk dijadikan cikal bakal aksi perubahan yang akan tertuang dalam laporan Stula dan peserta juga memberika rekomendasi kepada lokus stula setelah melaksanakan stula selanjutnya hasil adopsi best practice itu diadopsi oleh peserta kedalam rancangan aksi perubahan masing masing peserta yang nanti akan diadaptasikan ditempat tugas/ instansi masing masing.

\section{METODE PENELITIAN}

Kegiatan Studi Lapangan yang biasa dilakukan adalah:

1. Observasi Observasi menurut Guba dan Lincoln, ada beberapa alasan mengapa dalam penelitian kualitatif, observasi/pengamatan dimanfaatkan sebesar besarnya. Teknik pengamatan ini didasarkan atas pengalaman secara langsung. Tampaknya pengamatan langsung merupakan alat yang ampuh untuk mengetes suatu kebenaran. Jika suatu data yang diperoleh kurang meyakinkan, biasanya peneliti ingin menanyakannya kepada subyek, tetapi karena ia hendak memperoleh keyakinan tentang keabsahan data tersebut, jalan yang ditempuh adalah mengamati sendiri yang berarti mengalami langsung peristiwanya. Teknik pengamatan juga memungkinkan melihat dan mengamati sendiri, kemudian mencatat perilaku dan kejadian sebagaimana yang terjadi pada keadaan sebenarnya. Pengamatan memungkinkan 
peneliti mencatat peristiwa dalam situasi yang berkaitan dengan pengetahuan proporsional maupun pengetahuan yang langsung diperoleh dari data.

2. Wawancara Menurut Black \& Champion, "Wawancara adalah teknik penelitian yang paling sosiologis karena bentuknya yang berasal dari interaksi verbal antara peneliti dan responden dan juga cara yang paling baik untuk menentukan kenapa seseorang bertingkah laku, dengan menanyakan secara langsung." (Black \& Champion, 1992: 305). Singkatnya, wawancara berarti mengadakan aktivitas tanya jawab secara langsung kepada responden.

3. Studi Dokumentasi Dokumentasi Menurut McDonough dan Garrett yaitu: "Dokumentasi adalah merupakan sejumlah bahan bukti yang terekam/tercatat yang memperlihatkan karakteristik-karakteristik dari sebagian atau semua dari suatu sistem manajemen, termasuk di dalamnya: seluruh berkas bahan bukti tentang pilihan-pilihan ataupun keputusan-keputusan yang pernah dibuat sebelumnya selama pengkajian suatu sistem."(maksudnya, pembinaan dan pengembangan sistem informasi manajemen). Dalam studi dokumentasi dapat diartikan sebagai pencatatan atau perekaman suatu peristiwa/obyek yang dilanjutkan dengan kegiatan penelusuran lebih lanjut serta pengolahan atasnya sehingga menjadi sekumpulan/seberkas bahan bukti yang perlu dibuat dan ditampilkan kembali bila diperlukan pada waktunya, ataupun sebagai pelengkap atas laporan yang sedang disusunnya. Ilmu dokumentasi itu sendiri semula berasal dari ilmu perpustakaan, dan mungkin saja ia dapat dipandang sebagai bagian dari ilmu perpustakaan itu sendiri dalam artian yang luas. Banyak teknik yang digunakan oleh para pustakawan dipandang esensial oleh para dokumentalis, walaupun pada tahap perkembangan selanjutnya oleh para dokumentalis diberikan penekanan-penekanan yang jauh berbeda dari yang semula. Yang telah menjadi pokok argumentasinya adalah para dokumentalis, terutama sekali. Tidak berkepentingan atas penanganan buku-buku, pamflet, dan bahan sejenisnya sebagai unit-unit, tetapi mereka lebih banyak berkepentingan atas penyusunan/pengolahan informasi yang terkandung dalam dokumen-dokumen itu sendiri bersama-sama dengan data-data dari sumber-sumber informasi lainnya untuk dijadikan suatu kumpulan data/informasi yang baru. Dengan cara ini peneliti memperoleh suatu gambaran dan informasi yang lebih jelas

4. Dengan tugas memberi penjelasan dan bimbingan tentang kegiatan studi Lapangan, meliputi pelaksanaan bembingan di kelas dan bimbingan di lapangan. b) Pembimbing dari Instansi yang menjadi objek Studi Lapangan, dengan tugas sebagai berkut: 1) Memberi penjelasan Gambaran Umum daerah studi 2) Memberi bimbingan di lapangan 3) Memfasilitasi, menyediakan data-data yang dibutuhkan Presentasi

5. Presentasi adalah penyajian atau penyampaian karya tulis atau karya ilmiah seseorang di depan forum undangan/peserta atau suatu kegiatan berbicara di depan masyarakat/khalayak ramai (audiens), dalam rangka mengajukan suatu ide atau gagasan untuk mendapatkan pemahaman atau kesepakatan bersama. Kehadiran peserta dalam presentasi bermanfaat untuk membuat presentasi secara lebih aktif dan lancar, serta efisien dalam jangka waktu yang ditentukan. Orang yang menyampaikan presentasi disebut presentator atau presenter, sedangkan orang yang menghadiri presentasi disebut audience. Agar presentasi itu dapat berjalan secara selektif, ada beberapa hal yang perlu diperhitungkan. Hal yang dimaksudkan tersebut adalah sebagai berikut: a) Menarik minat dan perhatian peserta b) Mengarahkan perhatian peserta

\section{HASIL DAN PEMBAHASAN}

Menurut Tripomo (2005:89) key success factors adalah faktor-faktor internal organisasi yang paling kritis atau yang paling penting, yang mungkin digunakan oleh suatu organisasi untuk menangani peluang dan ancaman agar dapat bertahan dan memenangkan persaingan (meningkatkan dari internal pada umumnya dalam bentuk kekuatan (strength) dan 
kelemahan (weakness), sedangkan isu eksternal muncul dalam bentuk peluang (oppurtunity) dan tantangan (threaths). Dalam mengelola berbagai isu yang berkembang,digunakan Analisis SWOT untuk mengidentikasikandan merumuskan strategi yang paling tepat untuk diterapkan sesuai dengan kondisi organisasi. Pengidentifikasian isu-isu tersebut adalah sebagai berikut : posisi persaingan).

Dalam rangka pengembangan pelayanan, Dinas Komunikasi dan Informatika Jawa Barat dituntut untuk lebih responsif terhadap berbagai isu yang berkembang baik dari internal maupun eksternal. Berikut adalah langkah pelaksanaan kegiatan penelitian dimana dalam setiap

Tabel 1. Pelaksanaan Kegiatan Stula PKA

\begin{tabular}{|c|c|c|}
\hline No & Pelaksanaan Kegiatan & Waktu \\
\hline \multicolumn{3}{|c|}{ I. Tahap Awal } \\
\hline 1. & $\begin{array}{l}\text { Terbentuk Kelompok yang terdiri dari } 10 \text { orang peserta dari } \\
\text { penyelenggara Pelatihan Kepemimpinan Administrator, dan } \\
\text { mendapatkan lokus studi lapangan dari penyelenggara Pelatihan } \\
\text { Kepemimpinan Administrator. yaitu Dinas kominfo Provinsi } \\
\text { Jawa Barat }\end{array}$ & $8 / 3 / 2021$ \\
\hline 2 & $\begin{array}{l}\text { Diskusi bersama antara peserta didik dengan pembimbing : team } \\
\text { peserta menerima saran dan masukan dari pembimbing } \\
\text { mengenai teknis kolaborasi Tim dalam mengadopsi key success } \\
\text { factor dari Lokus dilanjutkan menyiapkan instrument kegiatan } \\
\text { dan lembar kerja. }\end{array}$ & $9 / 3 / 2021$ \\
\hline \multicolumn{3}{|c|}{ II. $\quad$ Pembimbingan Stula } \\
\hline 3 & $\begin{array}{l}\text { Persiapan pengamatan :. Mengumpulkan Bahan, } \\
\text { Menganalisis dan menginterpretasi data/ informasi } \\
\text { data lokus stula }\end{array}$ & $\begin{array}{c}15 / 3 / 201 \\
8\end{array}$ \\
\hline 4 & $\begin{array}{l}\text { Mengindentifikasi KSF (Keunggulan Strategi dan Mgt } \\
\text { Kinerja Pelayanan Publik di Lokus; }\end{array}$ & $\begin{array}{c}16 / 3 / 201 \\
8\end{array}$ \\
\hline \multirow[t]{2}{*}{5} & $\begin{array}{l}\text { Menetapkan KSF yang dominan dalam } \\
\text { meningkatkan keunggulan strategi danmgt } \\
\text { kinerja dan pembobotan kinerja; }\end{array}$ & $\begin{array}{c}16 / 3 / 201 \\
8\end{array}$ \\
\hline & $\begin{array}{ll}\text { III. Tahap Pembimbingan Pembuatan Laporan } \\
\text { Kelompok Stula }\end{array}$ & \\
\hline \multirow[t]{2}{*}{6} & $\begin{array}{l}\text { Pembuatan makalah penelitian : Menyusun Laporan } \\
\text { Kelompok; } \\
\text { Diawali dengan Diskusi Kelompok. }\end{array}$ & $\begin{array}{l}17 / 3 / 202 \\
1 \mathrm{sd} \\
18 / 3 / 202 \\
1\end{array}$ \\
\hline & $\begin{array}{l}\text { IV. Tahap Penyampaian Rekomendasi kepada } \\
\text { Lokus }\end{array}$ & \\
\hline \multirow[t]{2}{*}{7} & $\begin{array}{l}\text { Menyampaikan Rekomendasi per Kelompok } \\
\text { MenggunakanZoom yang dipimpin/didampingi oleh } \\
\text { Pembimbing. }\end{array}$ & $\begin{array}{c}19 / 3 / 202 \\
1\end{array}$ \\
\hline & Tahap Pembimbingan Laporan Individu & \\
\hline \multirow[t]{2}{*}{8} & $\begin{array}{l}\text { Mendampingi peserta Menyusun Draft Laporan Individu } \\
\text { sebagai cikal bakal rancangan aktualisasi }\end{array}$ & $\begin{array}{c}20 / 3 / 202 \\
1 \\
\text { s/d } \\
21 / 3 / 202 \\
1\end{array}$ \\
\hline & Tahap Presentasi & \\
\hline
\end{tabular}


10 Mendampingin peseta dalam memPresentasi hasil studi 22/3/202

Lapangan dimana video studi Lapangan mendapat dukungan 1

dari bapak Gubernur, bapak plt Sekda dan bapak Kepala

BPSDM Provinsi Riau.

Lesson Learnt yang didapatkan / diadopsi dari lokus yang direncanakan akan diadaptasi pada rancangan aksi perubahan masing masing peserta pada instansi masing masing dengan kapasitas peserta sebagai pejabat administrator adalah:

\section{Peran Kepemimpinan}

Karateristik Pemimpin diantaranya memiliki kemampuan untuk memproyeksikan tujuan organisasi kedalam program strategis dan realitis dengan strategi strategi yang tepat dalam mengembangkan praktek praktek yang organisasi yang lebih relevan Bass dan Avolio (1994) dalam journal kepemimpinan transformasional dan budaya organisasi transformasional dan budaya organisasi mengemukakan 4 (empat) dimensi kepemimpinan transformasional yaitu

1) Dimensi pertama idealized influence (pengaruh ideal), artinya perilaku seorang pemimpin harus menjadi suri tauladan dalam organisasinya.

2) Dimensi Kedua inspirational motivation (motivas seorang pemimpin harus mempertahankan organisasi. dipertahankan secara konsisten dan disepakati organisasi. Memperlihatkan komitmen yang tinggi

3) terhadap tujuan organisasi dan mampu mengartikulasikan pengharapan yang jelas atas kinerja organisasi.

4) Dimensi tiga intellectual stimulation (stimulasi intelektual). Dimensi ini mengandung makna seorang pemimpin harus mampu berperan menumbuh kembangkan ide-ide kreatif untuk melahirkan inovasi.

Adapun kebijakan strategis yang telah dilakukan oleh pemimpin dalam hal ini Kepala Dinas Komunikasi dan Informatika Provinsi Jawa Barat adalah :

1) Membuat program-program penyebarluasan informasi Sapa warga, dengan berkoordinasi langsung ke RW. Pendistribusian informasi program-program Pemerintah langsung melalui perangkat aplikasi yang telah diperuntukan ke lebih dari 40 ribu RW secara langsung;

2) Penggunaan teknologi dalam upaya penyebarluasan informasi program pemerintah melalui wifi jumlahnya \pm 150 wifi yang digratiskan di masyarakat, yang konten awalnya adalah mensosialisasikan program- program pemerintah;

3) Upaya penyebarluasan informasi juga memanfaatkan media sosial yang baik (facebook, instagram, dll);

4) Strategi lain untuk menyebarluaskan informasi juga melalui billboard, sukarelawan dan tim yang membantu penyebarluasan informasi secara langsung ke masyarakat luas melalui koordinasi dengan kab/kota.

5) Dimensi Empat (Individualized consideration) konsiderasi individu. Artinya seorang pemimpin harus memiliki kemampuan berinteraksi dengan bawahan. Keempat dimensi kepemimpinan sebagai agen perubahan diatas dapat menjadi suatu kekuatan atau energi yang dapat menggerakkan, memelihara keseimbangan dan inspirasi).

\section{Tabel 2. Indikator Kepemimpinan}

\begin{tabular}{|c|c|}
\hline Indikator Kepemimpinan & $\begin{array}{c}\text { Peran Pemimpin dilingkungan Diskominfo } \\
\text { Provinsi Jawa Barat }\end{array}$ \\
\hline $\begin{array}{l}\text { 1. Charismatic Leadership } \\
\text { (Kharismatik/pengaruh terhadap }\end{array}$ & $\begin{array}{l}\text { Pemimpin mempunyai power dan pengaruh. } \\
\text { Karyawan dibangkitkan, sehingga }\end{array}$ \\
\hline
\end{tabular}




\begin{tabular}{|c|c|}
\hline individu) & $\begin{array}{l}\text { mempunyai tingkat kepercayaan dan } \\
\text { keyakinan. }\end{array}$ \\
\hline $\begin{array}{l}\text { 2. Inspirational Motivation (Motivasi } \\
\text { Inspiratif) }\end{array}$ & $\begin{array}{l}\text { Selalu memotivasi dan merangsang dalam } \\
\text { menyiapkan pekerjaan dengan cara } \\
\text { memberikan tantangan, antusiasme, dan } \\
\text { optimism yang ditujukan dengan selalu } \\
\text { mengkomunikasikan visi, misi, dan harapan- } \\
\text { harapan dengan tujuan agar bawahan } \\
\text { mempunyai komitmen yang tinggi untuk } \\
\text { mencapai tujuan. }\end{array}$ \\
\hline $\begin{array}{l}\text { 3. Intelectual Stimulation (Stimulasi } \\
\text { Intelektual) }\end{array}$ & $\begin{array}{l}\text { Pemimpin selalu menstimulasi bawahannya } \\
\text { secara intelektual, sehingga mereka menjadi } \\
\text { inovatif dan kreatif dalam menyelesaikan } \\
\text { masalah. }\end{array}$ \\
\hline $\begin{array}{l}\text { 4. Individualized Consideration } \\
\text { (Konsiderasi Individual) }\end{array}$ & $\begin{array}{l}\text { Pemimpin memberikan perhatian kepada } \\
\text { karyawan ssecara individual, seperti : } \\
\text { kebutuhan karyawan untuk berprestasi, } \\
\text { memberikan gaji, memberikan nasehat } \\
\text { kepada karyawan sehingga karyawan dapat } \\
\text { tumbuh dan berkembang }\end{array}$ \\
\hline
\end{tabular}

\section{Inovasi Pelayanan}

Inovasi pelayanan publik adalah suatu cara baru penyelenggaraan pelayanan publik yang lebih menarik, atraktif, kreatif untuk mempermudah dan mempercepat pelayanan kepada masyarakat sehingga lebih efisien dan efektif. Inovasi membawa perubahan baru, bisa merupakan temuan baru yang tidak berdasar kondisi yang sudah ada (discontinous innovation) bisa pula bersifat meneruskan yang berdasarkan pelayanan/ produk yang sudah ada (subtaning innovation). Namun, keduanya memerlukan sentuhan perubahan baru dalam penyelenggaraan pelayanan publik.

Menurut Wawan E Kuswandoro (2016) sebagai dasar teoritis, program inovasi pelayanan publik diukur dengan indikator :

1) Nilai lebih (relative advantage),

2) Kesesuaian dengan masalah (compatibility/ contextuality);

3) Daya jangkau (complexity);

4) Kemudahan diamati (observability;

5) Bisa dicoba (triability).

Inovasi yang dilaksanakan oleh Dinas Kominfo Jabar adalah sebagai berikut :

1) JABAR DIGITAL SERVICE

"Pusat Layanan Digital, Data, dan Informasi Geospasial

-Unit Pelaksana Teknis Daerah (UPTD) dibawah Dinas Komunikasi dan Informatika Provinsi Jawa Barat"

Visi “ Menjadikan Jawa Barat sebagai provinsi terdepan dalam penggunaan data dan teknologi untuk mendukung layanan publik dan perumusan kebijakan yang lebih responsif, adaptif, dan inovatif."

Misi :

a) Penggunaan Big Data untuk Sistem Pengambilan Kebijakan

b) Pengembangan Kehidupan Masyarakat melalui penggunaan teknologi Digital

c) Transformasi Digital Pemerintahan 


\section{2) DESA DIGITAL}

Sebuah program pemberdayaan dan peningkatan taraf hidup masyarakat desa melalui literasi digital, IoT, dan ragam inovasi digital. Desa Digital bertujuan mewujudkan desa-desa di Jawa Barat yang mandiri secara digital sehingga meningkatkan standar hidup masyarakatnya.

\section{3) TALESA (PUSAT DIGITAL DESA)}

Program yang akan didirikan di 5000-an desa di Jawa Barat, kerja sama dengan Tokopedia Center dari Tokopedia. Di dalamnya warga bisa membeli sembako dan produk murah via online dan diedukasi/dibantu untuk siap menjual produk desanya online ke seluruh Indonesia. TALESA Juga akan dipergunakan untuk pelayanan publik dan ruang interaksi terkait ekonomi desa dan teknologi.

\section{4) E-FISHERY}

Kampung Perikanan Digital ini adalah kampong perikanan pertama yang ada di Jawa Barat dan di Indonesia, yang ditujukkan untuk menyediakan teknologi pemberi pakan otomatis eFisheryFeeder, sarana produksi, pendampingan, serta akses pasar bagi pembudidaya. eFishery tidak berhenti sampai situ saja. Kampung Teknologi Perikanan di Palas. Merupakan kolaborasi e- Fishery dengan e-Grow perusahaan peer to peer lending dan bersama sama menyediakan ekosistem terpadu untuk memenuhi kebutuhan mitra pembudidaya ikan dan udang yang lebih aksesibel dan tepat guna.

\section{5) SAPAWARGA}

Sapawarga adalah aplikasi komunikasi dan layanan informasi dari publik terintegrasi bagi warga Jabar untuk menyalurkan aspirasi, memperoleh informasi, dan mengakses layanan pemerintah secara digital . Aplikasi ini diluncurkan secara resmi oleh Gubernur Ridwan Kamil pada tanggal 6 Desember 2019 digelaran “ Jabar digital and innovation Award"

\section{6) DATA ;}

Di Jawa Barat, portal Satu Data Jawa Barat menjadi terobosan untuk mewujudkan pemerintah yang lebih akuntabel dan transparan karena ketersediaan data yang terbuka dan pengambilan keputusan yang berbasis data.

\section{7) PIKOBAR}

Pusat Informasi dan Koordinasi Covid-19 Jabar (Pikobar) dibuat sebagai media komunikasi dan informasi penanganan Covid- 19 di Jawa Barat. Pikobar dapat diakses melalui website maupun aplikasi yang bisa diunduh di Appstore dan Playstore.

\section{8) SOLIDARITAS}

Aplikasi yang memudahkan masyarakat untuk mendapatkan informasi dan data terkait bantuan sosial di Provinsi Jawa Barat serta masyarakat dapat secara langsung melakukan pengecekan bantuan sosial yang didapatkan.

https://solidaritas.jabarprov.go.id

\section{9) JABAR COMMAND CENTER}

Jabar Command Center merupakan pusat visualisasi dan integrasi data Jawa Barat yang dilengkapi dengan berbagai infrastruktur untuk kegiatan monitoring, koordinasi \& pengambilan keputusan. Jabar Command Center bertempat di kawasan Gedung Sate, Kota Bandung 


\section{Kompetensi dan Pemberdayaan SDM}

Sumberdaya manusia merupakan kunci utama sebuah keberhasilan, baik jangka pendek, menengah maupun jangka panjang. Maka dari itu, fungsi dan peranan setiap sumberdaya manusia harus senantiasa mampu untuk berubah sesuai tuntuan zaman, kemampuan personal maupun non personal, seperti kondisi saat ini yang dimiliki oleh Dinas KOMINFO Provinsi Jawa Barat. Kompetensi yang dimiliki setiap individu/karyawan di lingkungan Dinas KOMINFO telah sesuai dengan tugas dan fungsi yang diemban masing- masing. Sesuai dengan tuntutan dunia kerja dan pelayanan publik saat ini, Dinas KOMINFO Jawa Barat sampai pada tahun 2021, 80 $\%$ karyawan telah diberikan Diklat/ peningkatan kompetensi sesuai tuntutan kerja dan pelayanan masyarakat. Bahkan, termasuk sumberdaya manusia yang berada di tingkat Kabupaten/Kota se Jawa Barat juga telah dilaksanakan hal yang sama.

Pelaksanaan program Dinas KOMINFO Jawa Barat sesuai dengan Visi dan Misi Gubernur, menjadikan Jawa Barat Digital yang saaat sekarang telah dinikmati oleh masyarakat Jawa Barat. Dalam rangka pelaksanaan program pemerintah, Dinas KOMINFO telah melaksanakan berbagai edukasi, baik untuk sumberdaya manusia di lingkungan Dinas KOMINFO Jawa Barat, Sumber daya Manusia yang berada di Lingkungan Dinas KOMINFO Kabupaten/Kota, bahkan juga untuk masyarakat secara umum. Edukasi yang dilaksanakan, baik langsung maupun tidak langsung, berupa media TV, media cetak maupun media sosial. Di samping itu, penyampaian berbagai informasi yang diperlukan oleh masyarakat,dengan memberikan brosur, laflet.

\section{Pembangunan Jejaring Kerja dan Kolaborasi Pemangku Kepemimpinan;}

Jejaring kerja menurut Wayne E. Braker dalam buku Networking Smart, tahun 1984 adalah proses aktif membangun dan mengelola hubungan- hubungan yang produktif. Jejaring merupakan hubungan yang luas dan kokoh baik personal maupun organisasi. Selanjutnya pengintegrasian kemampuan- kemampuan terpilih, bakatbakat, hubungan dan partner dengan dikatakan jejaring dalam organisasi merupakan suatu proses pemeliharaan, penumbuhan serta cara mengembangkan jejaring kerja yang kreatif dan strategis untukmeningkatkan kinerja organisasi. Pentingnya jejaring kerja adalah menimbulkan komitmen dari setiap unsur yang terkait dengan menempatkan setiap individu pada jejaring tersebut serta menjadi jembatan penghubung antara pribadi dengan kehidupan profesional dan antara satu institusi dengan institusi lainnya.

\section{Penerapan Manajemen Kinerja;}

Menurut Dessler (2003:322) definisi Manajemen Kinerja adalah: Proses mengonsolidasikan penetapan tujuan, penilaian, dan pengembangan kinerja ke dalam satu sistem tunggal bersama, yang bertujuan memastikan kinerja karyawan mendukung tujuan strategis perusahaan. Komitmen dalam pencapaian visi dan misi dinas kominfo Jabar yang telah dituangkan dalam dokumen rencana strategis, serta konsisten dalam melaksanakan program dan kegiatan dengan prinsip efektifitas dan akuntabilitas.

\section{Penerapan Manajemen Resiko;}

Pada Dinas Komunikasi dan Informatika Jawa Barat ditentukan level risiko sesuai dengan tingkatan risiko itu sendiri, untuk kedepannya akan diidentifikasi risiko eksternal berupa bencana alam, untuk risiko bencana alam juga akan ditentukan level dari bencana tersebut. Untuk keamanan sistem informasi melakukan sebagai berikut : 1. Penerapan SNI ISO/IEC 27001:2013 yang merupakan Standar Internasional Sistem Manajemen Keamanan Informasi yang dikenal dengan nama lain ISMS ( Information Security Management System ); 2. Indeks KAMI ( Keamananan Informasi ) yang 
merupakan aplikasi yang digunakan untuk assessment dan evaluasi tingkat kesiapan (kelengkapan dan kematangan) penerapan keamanan informasi

\section{Planning dan Budgeting}

Untuk mencapai visi "Terwujudnya Jawa Barat Juara Lahir Batin dengan Inovasi dan Kolaborasi”, maka Dinas Kominfo Provinsi Jawa Barat menjabarkan misi yang terkait dengan urusan pemerintahan Komunikasi dan Informatika, Persandian dan Statistik yaitu misi ke-5 "Mewujudkan tata kelola pemerintahan yang inovatif dan kepemimpinan yang kolaboratif antara Pemerintah Pusat, Provinsi dan Kabupaten/Kota".

\section{Pemanfaatan Teknologi}

Untuk mewujudkan VISI Provinsi JABAR yaitu Terwujudnya Jawa Barat Juara Lahir Batin dengan Inovasi dan Kolaborasi dan untuk mencapai salah satu tujuan pembangunan Jabar yaitu Terwujudnya Provinsi Jawa Barat yang Informatif maka Diskominfo Jabar akan mewujudkan Jabar sebagai Provinsi Digital yang berbasis data dan teknologi dalam mendukung pelayanan dan pengambilan kebijakan publik yang responsif, adaptif dan inovatif melalui penerapan Peraturan Gubernur Jawa Barat No. 22 Tahun 2018 tentang Pemanfaatan Sertifikat Elektronik di Lingkungan Pemerintah Provinsi Jawa Barat.

\section{KESIMPULAN}

Kesimpulan yang dapat diambil dari penulisan best practice yang didapat dari key success factor yang diadopsi dari lokus stula yang didapatkan setelah melewati proses pembimbingan dan kerja tim sesama perserta yang mana best practice yang didapatkan dari lokus stula yaitu Diskominfo provinsi Jawa Barat ini merupakan cikal bakal untuk diadaptasikan pada rancangan aksi perubahan peserta yang berkapasitas sebagai pejabat administrator yang akan diadaptasikan pada instansi masing masing peserta.

\section{DAFTAR PUSTAKA}

Baker, Wayne. ["Struktur Sosial Pasar Sekuritas Nasional".] American Journal of Sociology 89:775811. 1984

Bass, B.M. and Avolio, B.J. (1994). Improving Organizational Effectiveness through Transformational Leadership, Sage, Thousand Oaks.

Hubeis. A. V. S. (2010). Perilaku Masyarakat dalam Pemanfaat Information and Communication Technology dalam Mendukung Pengembangan Masyarakat Global. Jurnal pada Institut Pertanian Bogor.

Kalbin Salim \& Mira Puspa Sari (2014) Pengaruh Globalisasi Terhadap Dunia Pendidikan.

Kuswandoro, Wawan E, 2016, "Strategi Pemberdayaan Masyarakat Desa berbasis

Partisipasi (Pendekatan Good Village Governance Untuk Implementasi

Mubah. A Safaril. (2011). "Strategi meningkatkan daya tahan budaya lokal dalam menghadapi arus globalisasi”.Departemen Hubungan Internasional, FISIP, Universitas Airlangga

Munawir. 2012. Analisis Laporan Keuangan. Liberty. Yogyakarta.

Peraturan Kepala Lembaga Administrasi Negara Nomor 16 Tahun 2019, tentang Pelatihan Kepemimpinan Administrator (PKA),

Safril Mubah (2011) Strategi Meningkatkan Daya Tahan Budaya Lokal dalam Menghadapi Arus Globalisasi. Universitas Airlangga Surabaya : Volume 24 Nomor 4.

Black, J. A. \& Champion, . D. J., 1992. Metode dan Masalah Penelitian Sosial. Bandung: s.n. Tripomo, Tedjo dan Udan. 2005. Manajemen Strategi. Bandung :Rekayasa Sain 